\title{
Evaluasi Rasio Keuangan pada Kategori BUKU 3
}

\author{
Ellen Theresia Sihotang ${ }^{1 *}$, Ismayantika Dyah Puspasari², Anisa Utika Kurnia ${ }^{3}$ \\ ${ }^{1 * 3)}$ Prodi Manajemen, STIE Perbanas Surabaya \\ Jl Nginden Semolo 34/36/Wonorejo Timur 16, Surabaya, Jawa Timur 60118 \\ 2) Prodi Manajemen, Fakultas Ekonomi dan Bisnis, Universitas Nusantara PGRI Kediri \\ Jl Ahmad Dahlan No 76, Kediri, Jawa Timur 64112 \\ E-mail korespondensi: ellen@perbanas.ac.id ${ }^{1 *)}$
}

\begin{abstract}
ABSTRAK
Tujuan dari penelitian ini adalah untuk mengetahui elemen rasio keuangan yang mempengaruhi ROE pada Bank Umum Kegiatan Usaha (BUKU) III. Rasio keuangan yang digunakan adalah rasio kecukupan modal (Capital Adequacy Ratio/CAR), Loan to Deposit Ratio (LDR), Loan to Asset Ratio (LAR), Non Performance Loan (NPL), Beban Operasional terhadap Pendapatan Operasional (BOPO) dan Fee Based Income Ratio (FBIR). Metode pengambilan sampel menggunakan purposive sampling. Tiga bank yang memenuhi kriteria sampel adalah PT Bank Bukopin, Tbk; PT Bank Mayapada Tbk, dan PT Bank Mega, Tbk. Periode penelitian adalah 2015-2019. Teknik analisis data menggunakan regresi berganda. Hasil penelitian ini mengungkapkan bahwa CAR, LDR, NPL, BOPO dan FBIR secara simultan berpengaruh signifikan terhadap ROE. CAR, LDR, NPL, dan BOPO memiliki pengaruh negatif signifikan terhadap ROE, sedangkan FBIR tidak berpengaruh secara signifikan terhadap ROE. CAR merupakan variabel yang berpengaruh paling dominan terhadap ROE dengan kontribusi sebesar $51,4 \%$. Pemenuhan terhadap kecukupan modal bank mengindikasikan bahwa bank mampu menyerap sejumlah kerugian operasional secara efisien. Peningkatan CAR dapat menyebabkan penurunan laba dan ROE karena pengeluaran terhadap aset tertimbang menurut risiko lebih besar dibandingkan ketersediaan modal, sehingga perolehan laba dan ROE menurun. Penurunan nilai ROE berpengaruh juga pada menurunnya tingkat pengembalian bagi sejumlah investor.
\end{abstract}

Kata Kunci: Bank; BUKU III; Rasio Keuangan; ROE

\begin{abstract}
The purpose of this study was to determine the elements of financial ratio that affects ROE in Bank Umum Kegiatan Usaha (BUKU) III. The financial ratios used are the Capital Adequacy Ratio (CAR), Loan to Deposit Ratio (LDR), Loan to Asset Ratio (LAR), Non Performance Loan (NPL), Operational Efficiency Ratio and Fee Based Income Ratio. The sampling method used was purposive sampling. PT Bank Bukopin, Tbk; PT Bank Mayapada Tbk, and PT Bank Mega, Tbk are the sample of this study with the period of study is 2015-2019. The data analysis technique used multiple regression. The results of this study revealed that simultaneously CAR, LDR, NPL, OER and FBIR have a significant effect on ROE. $C A R, L D R, N P L$ and OER have a significant negative effect on ROE. FBIR has a negative insignificant effect on ROE. CAR as a dominant variable that influence on ROE with $51.4 \%$ contribution. An increase in CAR can lead to a decrease in profit and $R O E$ because the expenditure on risk-weighted asset is greater than the availability of capital, as a result decrease in earning and ROE. The decline in $R O E$ value also has an effect for a number of investors
\end{abstract}

Keywords: Bank, BUKU III, Financial Ratio, ROE 


\section{PENDAHULAN}

Sistem perbankan Indonesia dikelompokan berdasarkan kegiatan usahanya yang disesuaikan dengan modal inti yang dimiliki. Pada umumnya dikenal dengan istilah Bank Umum Kegiatan Usaha (BUKU) yang mengacu kepada Peraturan Otoritas Jasa Keuangan (POJK) No 6/POJK.03/2016. Pengelompokan bank dibagi menjadi 4 BUKU. Kategori BUKU 3 merupakan bank dengan modal inti paling sedikit sebesar Rp 5 triliun sampai dengan kurang dari Rp 30 triliun (Otoritas Jasa Keuangan, 2016a). Kegiatan usaha bank sebagai lembaga yang utamanya adalah menghimpun dana masyarakat dan menyalurkannya kembali kepada masyarakat, serta melaksanakan jasa-jasa keuangan lainnya. Ketiga aktivitas tersebut menggambarkan bank sebagai perantara antara pihak yang berkelebihan dana dengan yang kekurangan dana, oleh sebab itu peranan bank sebagai perantara harus mendapatkan kepercayaan dari masyarakat.

Bank sebagai pihak yang menghimpun dana masyarakat memiliki kewajiban untuk mengembalikan sejumlah dana masyarakat dengan tingkat pengembalian berdasarkan periode waktu yang telah disepakati. Pada kapasitas bank akan memperoleh tingkat pengembalian juga selama periode tertentu. Selisih tingkat pengembalian dari dana yang dihimpun dengan sejumlah dana yang disalurkan ke masyarakat menjadi pendapatan utama bank. Pendapatan ini dikenal dengan istilah spread based (Kasmir, 2015:15). Demikian juga dengan penyelenggaraan jasa-jasa perbankan lainnya, seperti jasa pengiriman uang dalam negeri atau luar negeri, jasa penitipan barang berharga dan beberapa jasa lainnya. Penyelenggaraan jasajasa perbankan dikenal dengan istilah fee based income.

Berkaitan dengan ketiga kegiatan bank tersebut maka pengelolaan usaha bank juga harus berdasarkan prinsip kehati-hatian. Aplikasinya melalui pengelolaan perbankan dengan baik. Salah satu ukurannya adalah pencapaian kinerja bank secara optimal. Pencapaian kinerja bank yang optimal dapat diketahui dari tingkat profitabilitasnya. Profitabilitas dalam akuntansi merupakan rasio yang mengukur kinerja entitas, terkait dengan keberhasilan atau kegagalan memperoleh laba pada periode waktu tertentu (Kieso, Weygandt, \& Warfield, 2018:385). Rasio profitabilitas atau rentabilitas pada bank merupakan pengukuran terhadap tingkat efisiensi usaha serta pencapaian profit pada waktu tertentu (Kasmir, 2015:327). Rasio profitabilitas terdiri dari Gross Profit Margin (GPM), Net Profit Margin (NPM), Return on Asset (ROA) serta ROE. ROE merupakan salah satu indikator yang digunakan untuk mengukur kemampuan bank memperoleh laba bersih dari sejumlah modal yang dimiliki (Rivai, Basir, Sudarto, \& Arifiandy Permata Veithzal, 2013). Perhitungan ROE pada perbankan mengacu pada ketentuan Surat Edaran OJK No.43/03/2016 yaitu laba setelah 
pajak dibagi dengan rata-rata ekuitas yang merupakan rata-rata modal inti (Tier 1) (Otoritas Jasa Keuangan, 2016b). Hal tersebut juga menjadi alasan mengapa pada penelitian ini menggunakan BUKU III. Secara umum semakin tinggi rasio ROE bank maka laba yang diperoleh juga semakin besar. Idealnya nilai ROE bank dari tahun ke tahun mengalami peningkatan, sebagai bukti peningkatan kinerja internal maupun eksternal secara khusus bagi sejumlah investor (Menicucci \& Paolucci, 2016; Reza, 2018). Namun, pada kenyataannya masih terdapat beberapa bank pada kategori BUKU III yang memiliki kecenderungan nilai ROE negatif. Beberapa diantaranya adalah seperti yang tercantum pada Tabel 1, perihal Perkembangan ROE pada sejumlah BUKU III.

Tabel 1. Perkembangan ROE BUKU III Periode 2015-2019

\begin{tabular}{|c|c|c|c|c|c|c|c|c|c|c|}
\hline Nama Bank & 2015 & 2016 & Tren & 2017 & Tren & 2018 & Tren & 2019 & Tren & $\begin{array}{l}\text { Rata-rata } \\
\text { Tren } \\
\text { ROE }\end{array}$ \\
\hline $\begin{array}{l}\text { PT. Bank Artha } \\
\text { Graha } \\
\text { Internasional, } \\
\text { Tbk }\end{array}$ & 2,93 & 2,11 & $-0,82$ & 1,71 & $-0,40$ & 1,43 & $-0,28$ & $-1,63$ & $-3,06$ & $-1,14$ \\
\hline $\begin{array}{l}\text { PT. Bank } \\
\text { Bukopin, Tbk }\end{array}$ & 14,8 & 13,19 & $-1,61$ & 1,85 & $-11,34$ & 2,95 & 1,10 & 3,17 & 0,22 & $-2,91$ \\
\hline $\begin{array}{l}\text { PT. Bank } \\
\text { Capital } \\
\text { Indonesia, Tbk }\end{array}$ & 9,59 & 7,82 & $-1,77$ & 7.17 & $-0,65$ & 10,55 & 3,38 & 1,20 & $-9,35$ & $-2,10$ \\
\hline $\begin{array}{l}\text { PT. Bank } \\
\text { China } \\
\text { Construction } \\
\text { Indonesia, Tbk }\end{array}$ & 6,21 & 1,16 & $-5,05$ & 2,46 & 1,30 & 4,34 & 1,88 & 4,15 & $-0,19$ & $-0,52$ \\
\hline $\begin{array}{l}\text { PT. Bank } \\
\text { Danamon } \\
\text { Indonesia, Tbk }\end{array}$ & 6,71 & 7,88 & 1,17 & 10,34 & 2,46 & 11,00 & 0,66 & 10,31 & $-0,69$ & 0,90 \\
\hline $\begin{array}{l}\text { PT. Bank } \\
\text { HSBC } \\
\text { Indonesia, Tbk }\end{array}$ & 0,64 & 0,02 & $-0,62$ & 0,12 & 0,10 & 5,95 & 5,83 & 13,78 & 7,83 & 3,29 \\
\hline $\begin{array}{l}\text { PT. Bank } \\
\text { Mayapada } \\
\text { Indonesia, Tbk }\end{array}$ & 23,41 & 19,00 & $-4,41$ & 10,64 & $-8,36$ & 14,18 & 3,54 & 5,92 & $-8,26$ & $-4,37$ \\
\hline $\begin{array}{l}\text { PT. Bank } \\
\text { Maybank } \\
\text { Indonesia, Tbk }\end{array}$ & 0,06 & 0,18 & 0,12 & 0,08 & $-0,10$ & 0,09 & 0,01 & 6,47 & 6,38 & 1,60 \\
\hline $\begin{array}{l}\text { PT. Bank } \\
\text { Mega, Tbk }\end{array}$ & 15,3 & 10,91 & $-4,39$ & 11,66 & 0,75 & 13,08 & 1,42 & 14,85 & 1,77 & $-0,11$ \\
\hline $\begin{array}{l}\text { PT. Bank } \\
\text { OCBC NISP, } \\
\text { Tbk }\end{array}$ & 9,60 & 9,85 & 0,25 & 10,66 & 0,81 & 12,26 & 1,60 & 11,58 & $-0,68$ & 0,50 \\
\hline $\begin{array}{l}\text { PT. Bank } \\
\text { Permata, Tbk }\end{array}$ & 1,80 & $\begin{array}{l}- \\
38,33\end{array}$ & $\begin{array}{l}- \\
40,13\end{array}$ & 4,83 & 43,16 & 3,69 & $-1,14$ & 7,20 & 3,51 & 1,35 \\
\hline $\begin{array}{l}\text { PT. Bank QNB } \\
\text { Indonesia, Tbk }\end{array}$ & 7,50 & $\begin{array}{l}- \\
21,96\end{array}$ & 29,46 & $\begin{array}{l}- \\
26,95\end{array}$ & $-4,99$ & $-6,33$ & 20,62 & 0,05 & 6,38 & $-1,86$ \\
\hline $\begin{array}{l}\text { PT. Bank } \\
\text { Rakyat } \\
\text { Indonesia } \\
\text { Agroniaga, Tbk }\end{array}$ & 7,65 & 0,07 & $-7,58$ & 0,06 & $-0,01$ & 6,82 & 6,76 & 1,16 & $-5,66$ & $-1,62$ \\
\hline
\end{tabular}




\begin{tabular}{|c|c|c|c|c|c|c|c|c|c|c|}
\hline $\begin{array}{l}\text { PT. Bank } \\
\text { Sinarmas, Tbk }\end{array}$ & 6,46 & 10,04 & 3,58 & 7,51 & $-2,53$ & 7,55 & 0,04 & 0,14 & $-7,41$ & $-1,58$ \\
\hline $\begin{array}{l}\text { PT. Bank } \\
\text { Tabungan } \\
\text { Pensiunan } \\
\text { Nasional, Tbk }\end{array}$ & 14,11 & 12,58 & $-1,53$ & 5,53 & $-7,05$ & 9,53 & 4,00 & 9,94 & 0,41 & $-1,04$ \\
\hline $\begin{array}{l}\text { PT. Bank } \\
\text { Woori Saudara } \\
\text { Indonesia } \\
\text { 1906, Tbk }\end{array}$ & 12,16 & 13,06 & 0,90 & 14,21 & 1,15 & 13,01 & $-1,20$ & 11,08 & $-1,93$ & $-0,27$ \\
\hline
\end{tabular}

Sumber Data: Data Otoritas Jasa Keuangan/OJK, diolah

Berdasarkan perhitungan tren rasio ROE dari 2015-2019 terhadap sejumlah bank kategori BUKU III terdapat 10 bank yang rata-rata kecenderungan nilai ROE negatif (minus), formula perhitungannya adalah sebagai berikut:

$$
\mathrm{ROE}=\frac{\text { Laba Bersih }}{\text { Ekuitas Modal }} \times 100 \%
$$

Profitabilitas bank pada umumnya dinyatakan sebagai fungsi penentu secara internal dan eksternal. Secara khusus yang terpenting adalah faktor internal (Menicucci \& Paolucci, 2016). Secara empiris faktor penentu internal dalam pencapaian tingkat profitabilitas bank yang tinggi adalah rasio likuiditas (Bourke, 1989; Molyneux \& Thornton, 1992). Pengujian sejumlah rasio tersebut terhadap ROE secara simultan berpengaruh secara signifikan (Aprilia \& Handayani, 2018; Nimah \& Maguni, 2019; Saputri \& Oetomo, 2016; Vellanita, Arimbawa, \& Damayanti, 2019). Berdasarkan hasil empiris tersebut maka rasio keuangan yang digunakan pada penelitian ini adalah rasio modal, rasio likuiditas, kualitas aset, serta efisiensi.

Modal pada bank menjadi bagian terpenting sehingga semua bank diwajibkan memenuhi kecukupan modal yang memadai dalam rangka menjaga tingkat likuiditasnya (Rivai et al., 2013). Pengukuran rasio kecukupan modal (Capital Adequacy Ratio) atau yang seringkali disebut dengan CAR adalah sebagai berikut:

$$
\mathrm{CAR}=\frac{\text { Modal }}{\text { Aset Tertimbang Menurut Risik }} \times 100 \%
$$

Mengacu pada Peraturan OJK No 11/POJK.03/2016 perihal Kewajiban Penyediaan Modal Minimum Bank Umum, sejumlah bank di Indonesia wajib memenuhi kecukupan modalnya minimal sebesar $8 \%$. Pemenuhan modal minimum oleh bank menjadi penting karena berkaitan dengan kemampuan bank dalam menjalankan kegiatan operasionalnya secara efisien. Secara konsep pengaruh CAR terhadap ROE adalah positif, namun beberapa hasil penelitian ada yang berpengaruh secara positif maupun negatif signifikan. Berdasarkan hasil penelitian sebelumnya secara secara parsial CAR berpengaruh positif signifikan terhadap ROE (Saputri \& Oetomo, 2016). Sementara penelitian lainnya menyatakan CAR secara parsial berpengaruh negatif signifikan terhadap ROE (Aprilia \& Handayani, 2018; 
Eka Agustyn Nurhayati, Sudiyatno, \& Elen Puspitasari, 2019; Nimah \& Maguni, 2019; Vellanita et al., 2019).

Pada perbankan pengertian likuiditas, apabila bank memiliki alat pembayaran berupa aset lancar yang jumlahnya lebih besar dibandingkan dengan seluruh liabilitasnya atau kewajibannya. (Rivai et al., 2013). Pengukuran likuiditas bank dapat menggunakan LDR dan LAR (Jumono, Sugiyanto, \& Mala, 2019). Rivai et al. (2013) menjelaskan LDR sebagai perbandingan antara jumlah pinjaman yang diberikan bank terhadap dana pihak ketiga yang diterima oleh bank yang diformulasikan sebagai berikut:

$$
\text { LDR }=\frac{\text { Jumlah Kredit yang Diberikan }}{\text { Total Dana Pihak Ketiga }} \times 100 \%
$$

Semakin tinggi nilai LDR maka semakin tinggi tingkat likuiditas bank dalam mengelola sejumlah pinjaman dari total dana pihak ketiga yang dimiliki. Artinya perolehan laba juga semakin meningkat dan menyebabkan ROE meningkat (Jumono et al., 2019; Rivai et al., 2013). Hasil penelitian sebelumnya mengungkapkan bahwa secara parsial LDR memiliki pengaruh positif signifikan dan hasil ini sejalan dengan teori (Eka Agustyn Nurhayati et al., 2019)

LAR merupakan perbandingan jumlah pinjaman yang diberikan terhadap jumlah aset yang dimiliki (Rivai et al., 2013). Perhitungan LAR dapat diformulasikan sebagai berikut:

$$
\mathrm{LAR}=\frac{\text { Jumlah Kredit yang Diberikan }}{\text { Jumlah Aset }} \times 100 \%
$$

Pencapaian rasio LAR bank yang tinggi mengindikasikan tingginya tingkat likuiditas bank, karena jumlah aset yang dimiliki untuk membiayai sejumlah pinjaman semakin besar. Semakin tinggi nilai LAR maka semakin tinggi tingkat likuiditas bank sehingga laba juga meningkat dan menyebabkan peningkatan ROE (Jumono et al., 2019). Konseptual LAR secara parsial memiliki pengaruh positif signifikan terhadap ROE,dibuktikan dari hasil penelitian sebelumnya oleh Jumono et al. (2019) dan Reza (2018).

Pengukuran terhadap kualitas aset menggunakan Non Performing Loan (NPL). Kualitas aset berkaitan penilaian kondisi aset serta kecukupan manejemen risiko kredit atau pinjaman yang disalurkan (Rivai et al., 2013). Berdasarkan lampiran POJK 03/2018 tentang Laporan Periodik Bank Umum menjelaskan perihal kualitas aset bank yang salah satunya diukur dengan NPL. Formulasi perhitungannya adalah sebagai berikut:

$$
\text { NPL }=\frac{\text { Kredit Bermasalah }}{\text { Total Kredit }} \times 100 \%
$$

Berdasarkan formula tersebut kategori kredit bermasalah yang diperhitungkan adalah kredit dengan kategori kurang lancar, diragukan dan macet yang tercatat secara gross pada laporan 
posisi keuangan sebelum dikurangi dengan nilai CKPN (Otoritas Jasa Keuangan, 2018). Mengacu pada POJK No 33/POJK.03/2018 dan formulasi perhitungan NPL maka rasio NPL yang tinggi mengindikasikan semakin rendah kualitas aset bank yang berkaitan dengan sejumlah kredit yang disalurkan. Apabila rasio NPL meningkat maka mengindikan terjadinya penurunan laba sehingga nilai ROE juga menurun, demikian juga sebaliknya. Hasil dari penelitian sebelumnya secara parsial mengungkapkan NPL memiliki pengaruh negatif signifikan terhadap ROE (Prasanto, 2020; Reza, 2018; Saputri \& Oetomo, 2016).

Pengukuran efisiensi pada perbankan menggunakan rasio Beban Operasional terhadap Pendapatan Operasional (BOPO) dan Fee Based Income Ratio (FBIR). BOPO merupakan rasio yang mengukur tingkat efisiensi serta kemampuan bank dalam menjalankan kegiatan operasinya (Rivai et al., 2013). Perhitungannya sebagai berikut:

$$
\mathrm{BOPO}=\frac{\text { Beban Operasional }}{\text { Pendapatan Operasional }} \times 100 \%
$$

Semakin kecil rasio BOPO suatu bank maka menggambarkan semakin efisien bank tersebut menjalanlan kegiatan usahanya (Susilowati \& Tiningrum, 2019). Apabila dihubungkan dengan perolehan ROE adalah jika semakin rendah rasio BOPO maka semakin tinggi perolehan laba bank sehingga rasio ROE juga semakin meningkat. Jika rasio BOPO mengalami peningkatan artinya terjadi kenaikan pada beban operasional yang lebih besar dibandingkan dengan pendapatan operasional sehingga peningkatan pendapatan operasional lebih kecil dibandingkan dengan peningkatan beban pencadangan (CKPN) (Reza, 2018). Hasil studi sebelumnya BOPO secara parsial berpengaruh negatif signifikan terhadap ROE (Aprilia \& Handayani, 2018; Nimah \& Maguni, 2019; Reza, 2018; Rusiyati, 2018).

FBIR merupakan pendapatan operasional bank selain dari bunga bank (Rivai et al., 2013). Perolehan pendapatan operasional ini biasanya dari jasa pengiriman uang, penitipan barang berharga, penarikan tunai melalui counter teller dan lain sebagainya. Formula perhitungan dari FBIR adalah sebagai berikut:

$$
\text { FBIR }=\frac{\text { Pendapatan Operasional Diluar Pendapatan Bunga }}{\text { Pendapatan Operasional }} \times 100
$$

Konstruk dari FBIR adalah apabila semakin tinggi tentunya meningkatkan laba bank sehingga nilai ROE juga meningkat. Artinya FBIR memiliki pengaruh positif terhadap ROE. Pengujian secara parsial dari beberapa studi sebelumnya menyatakan FBIR berpengaruh positif signifikan terhadap ROE (Jumono, Sugiyanto, \& Mala, 2019; Sufian \& Chong, 2008)

Tujuan dari penelitian ini adalah untuk mengetahui rasio apa saja yang mempengaruhi nilai ROE, sehingga pengelolaan kinerja bank terhadap sejumlah ekuitas yang dimiliki dapat menjadi optimal. 


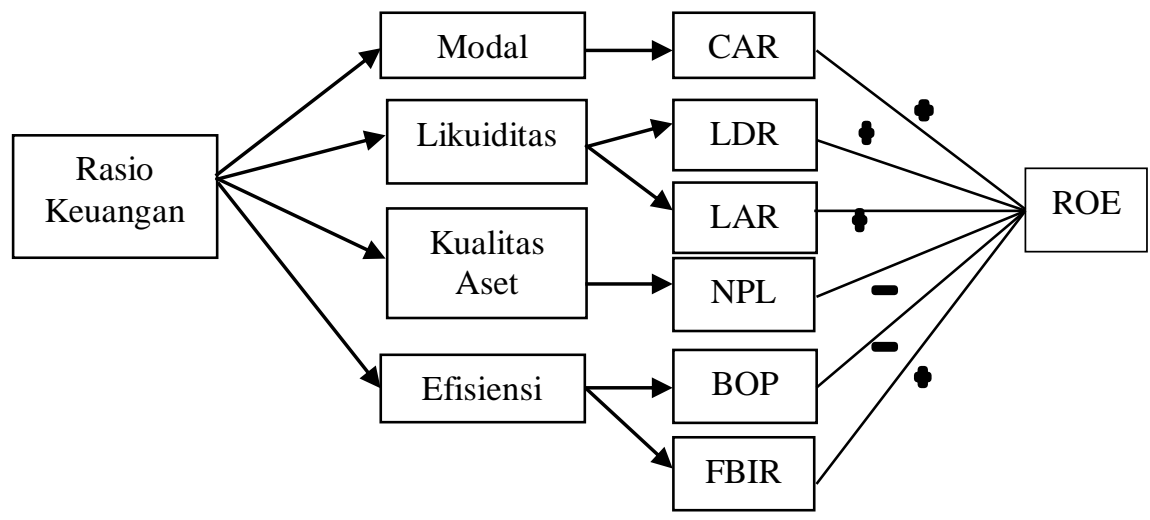

Gambar 1. Kerangka Pemikiran

Maka perumusan hipotesis adalah sebagai berikut:

Hipotesis 1 : Rasio modal, likuiditas, kualitas aset dan efisiensi secara simultan berpengaruh signifikan terhadap ROE BUKU III

Hipotesis $_{2}$ : Rasio Kecukupan Modal secara parsial berpengaruh positif signifikan terhadap ROE BUKU III

Hipotesis $_{3}$ : LDR secara parsial berpengaruh positif signifikan terhadap ROE BUKU III Hipotesis$_{4}$ : LAR secara parsial berpengaruh positif signifikan terhadap ROE BUKU III Hipotesis5 : NPL secara parsial berpengaruh negatif signifikan terhadap ROE BUKU III Hipotesis6 : BOPO secara parsial berpengaruh negatif signifikan terhadap ROE BUKU III Hipotesis7 : FBIR secara parsial berpengaruh positif signifikan terhadap ROE BUKU III

\section{METODE PENELITIAN}

Penelitian ini mengevaluasi rasio keuangan yang meliputi kecukupan modal, likuiditas, kualitas aset dan efisiensi terhadap profitabilitas yang diukur dengan ROE pada BUKU III yang bersumber dari Laporan Keuangan Tahunan BUKU III dan repositori Otoritas Jasa Keuangan (OJK) periode 2015-2019.

Teknik pengolahan data menggunakan analisis regresi berganda untuk menganalisis pengaruh simultan maupun parsial dari sejumlah rasio keuangan terhadap ROE. Tingkat signifikansi yang digunakan pada regresi berganda profitabilitas adalah $\alpha=5 \%$. Model persamaannya diformulasikan sebagai berikut:

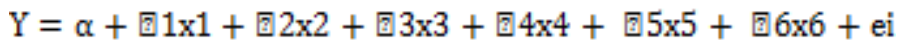

Keterangan:

$\mathrm{Y}=\mathrm{ROE}$ (Profitabilitas)

$\alpha=$ Konstanta

$\beta_{1-6}=$ Koefisien regresi

$\mathrm{x}_{1}=\mathrm{CAR}$ 


$$
\begin{array}{ll}
\mathrm{x}_{2} & =\mathrm{LDR} \\
\mathrm{x}_{3} & =\mathrm{LAR} \\
\mathrm{x}_{4} & =\mathrm{NPL} \\
\mathrm{x}_{5} & =\mathrm{BOPO} \\
\mathrm{x}_{6} & =\mathrm{FBIR} \\
\mathrm{e}_{\mathrm{i}} & =\text { error }
\end{array}
$$

Populasi dari penelitian ini adalah Bank Umum Kegiatan Usaha III. Kelompok bank yang kegiatan usahanya berdasarkan pada modal inti senilai Rp 5 triliun sampai dengan kurang dari $\mathrm{Rp} 30$ triliun. Kegiatan usahanya meliputi penghimpunan dan penyaluran sejumlah dana beserta jasa-jasa lainnya, dengan mata uang rupiah maupun asing beserta penyertaan modal pada lembaga keuangan di Indonesia maupun di luar negeri, namun terbatas pada wilayah regional Asia (Otoritas Jasa Keuangan, 2016a). Populasi BUKU III beserta nilai total aset, modal dan kecenderungan nilai ROE tercantum pada Tabel 2 perihal populasi BUKU III.

Pengambilan sampel dilakukan dengan metode purposive sampling. Adapun kriteria sejumlah sampel pada studi ini adalah sebagai berikut:

1. Bank dengan kepemilikan total aset senilai Rp 90-120 triliun

2. Bank yang memiliki rata-rata kecenderungan nilai ROE negatif.

3. Bank yang telah terdaftar pada Bursa Efek Indonesia (Go Public) dan merupakan bank devisa.

Berdasarkan kriteria tersebut maka sampel dari penelitian ini adalah PT Bank Bukopin Tbk, PT Bank Mayapada Tbk dan PT Bank Mega Tbk. Jenis data yang digunakan pada studi ini adalah data sekunder, berupa laporan keuangan BUKU III. Metode pengumpulan data adalah dokumentasi yang diperoleh dari situs web bank sampel maupun OJK. Periode laporan keuangan yang digunakan adalah 2015-2019. Pengolahan data menggunakan perangkat lunak Statistical Product and Service Solutions (SPSS) versi 20. Metode analisis data dilakukan melalui tahapan uji asumsi klasik, analisis deskriptif dan regresi berganda. Analisis deskriptif memberikan gambaran kecenderungan nilai rasio variabel dependen terhadap independen selama peirode penelitian. Analisis regresi berganda dilakukan melalui tahapan uji simultan (uji F) dan uji parsial (uji t). 
Tabel 2. Populasi BUKU III

\begin{tabular}{lcccc}
\hline \multicolumn{1}{c}{ Nama Bank } & $\begin{array}{c}\text { Total } \\
\text { Aset } \\
\text { (Jutaan Rp) }\end{array}$ & $\begin{array}{c}\text { Total } \\
\text { Modal } \\
\text { (Jutaan Rp) }\end{array}$ & $\begin{array}{c}\text { Rata-rata } \\
\text { Tren ROE }\end{array}$ & $\begin{array}{c}\text { Izin Bank } \\
\text { Devisa }\end{array}$ \\
\hline PT. Bank Artha Graha Internasional, Tbk & 25.532 .041 & 3.548 .549 & $-1,14$ & $24 / 02 / 93$ \\
PT. Bank Bukopin, Tbk & 94.796 .657 & 8.234 .148 & $-2,91$ & $02 / 12 / 97$ \\
PT. Bank Capital Indonesia, Tbk & 18.959 .622 & 1.561 .147 & $-2,10$ & $25 / 10 / 89$ \\
PT. Bank China Construction Indonesia, Tbk & 18.893 .684 & 2.852 .954 & $-0,52$ & $17 / 03 / 93$ \\
PT. Bank Danamon Indonesia, Tbk & 169.980 .944 & 33.445 .305 & 0,90 & $05 / 11 / 88$ \\
PT. Bank HSBC Indonesia, Tbk & $111,436,378$ & 19.667 .473 & 3,29 & $16 / 09 / 92$ \\
PT. Bank Mayapada Indonesia, Tbk & 93.408 .831 & 12.690 .303 & $-4,37$ & $03 / 06 / 93$ \\
PT. Bank Maybank Indonesia, Tbk & 154.703 .225 & 23.594 .673 & 1,60 & $09 / 10 / 88$ \\
PT. Bank Mega, Tbk & 100.803 .831 & 14.684 .721 & $-0,11$ & $31 / 01 / 01$ \\
PT. Bank OCBC NISP, Tbk & 180.809 .253 & 28.194 .846 & 0,50 & $19 / 05 / 90$ \\
PT. Bank Permata, Tbk & 161.451 .259 & 23.136 .186 & 1,35 & $08 / 05 / 56$ \\
PT. Bank QNB Indonesia, Tbk & 23.021 .785 & 3.659 .131 & $-1,86$ & $22 / 02 / 96$ \\
PT. Bank Rakyat Indonesia Agroniaga, Tbk & 27.067 .923 & 4.580 .127 & $-1,62$ & $08 / 05 / 06$ \\
PT. Bank Sinarmas, Tbk & 36.559 .556 & 5.702 .574 & $-1,58$ & $22 / 03 / 95$ \\
PT. Bank Tabungan Pensiunan Nasional, Tbk & 167.492 .734 & 30.987 .668 & $-1,04$ & $21 / 12 / 15$ \\
PT. Bank Woori Saudara Indonesia 1906, Tbk & 36.936 .262 & 4.939 .254 & $-0,27$ & $22 / 02 / 08$ \\
\hline Sumber: Direktori \& Lap & & & &
\end{tabular}

Sumber: Direktori \& Laporan Keuangan OJK

\section{HASIL DAN PEMBAHASAN}

Berdasarkan hasil uji multikolonieritas rasio likuiditas yang digunakan pada penelitian ini hanya LDR karena formula LDR secara khusus menghitung perbandingan kredit yang diberikan terhadap dana pihak ketiga yang dihimpun sebagai kegiatan operasional utama dari bank. Variabel LAR dikeluarkan dari model penelitian ini dan dilakukan uji model yang kedua. Hasil uji model yang kedua memberikan hasil bahwa tidak terjadi multikolonieritas diantara variabel bebas, karena nilai VIF variabel independen bernilai kurang dari 10. Hasil uji multikolonieritas secara rinci tercantum pada Tabel 3.

Tabel 3. Hasil Uji Multikolonieritas

\begin{tabular}{cccccc}
\hline Variabel & \multicolumn{2}{c}{ Model I } & \multicolumn{2}{c}{ Model II } & \\
& Toleransi & VIF & Toleransi & VIF & Keterangan \\
\hline CAR & $\mathbf{0 , 0 9 1}$ & $\mathbf{1 1 , 0 1 7}$ & $\mathbf{0 , 2 6 3}$ & $\mathbf{3 , 7 9 7}$ & Tidak Terjadi Gejala Multikolonieritas \\
LDR & $\mathbf{0 , 0 3 2}$ & $\mathbf{3 1 , 3 2 9}$ & $\mathbf{0 , 3 6 2}$ & $\mathbf{2 , 7 6 2}$ & Tidak Terjadi Gejala Multikolonieritas \\
LAR & $\mathbf{0 , 0 1 5}$ & $\mathbf{6 6 , 9 9 1}$ & - & - & Dikeluarkan dari Model \\
NPL & 0,356 & 2,809 & 0,353 & 2,835 & Tidak Terjadi Gejala Multikolonieritas \\
BOPO & 0,302 & 3,316 & 0,467 & 2,144 & Tidak Terjadi Gejala Multikolonieritas \\
FBIR & 0,293 & 3,416 & 0,296 & 3,382 & Tidak Terjadi Gejala Multikolonieritas
\end{tabular}


Hasil uji autokorelasi diperoleh nilai Durbin Watson (DW) hitung senilai 1,197 dengan nilai $\mathrm{DL}=1,408$ sehingga berada pada rentang $0<1,197<1,408$ yang artinya tidak terjadi autokorelasi pada residual data.

Tabel 4. Hasil Uji Autokorelasi

\begin{tabular}{cccccc}
\hline Model & $\mathbf{R}$ & R Square & $\begin{array}{c}\text { Adjusted } \mathbf{R} \\
\text { Square }\end{array}$ & $\begin{array}{c}\text { Std Error of } \\
\text { the Estimate }\end{array}$ & Durbin-Watson \\
\hline & & & & 2,85971 & 1,197 \\
& 0,888 & 0,788 & 0,768 & & \\
\end{tabular}

Sumber: Data Diolah, SPSS 20, 2020

Berdasarkan uji heteroskedastisitas tidak membentuk pola tertentu dan titik-titik tersebar secara acak disekitar titik nol pada sumbu Y, sehingga tidak terjadi heteroskedastisitas.

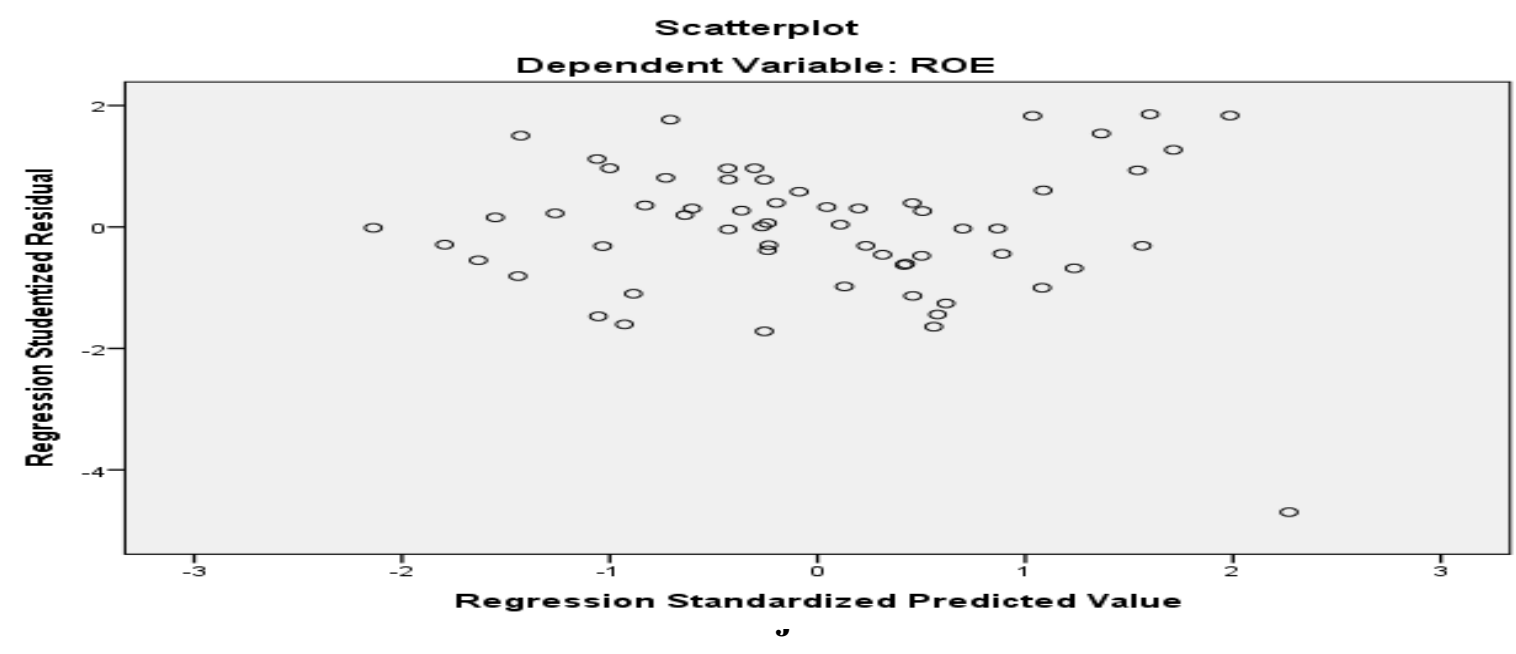

Sumber: Data Diolah, SPSS 20, 2020

Hasil uji normalitas dengan Kolmogorov-Smirnov pada variabel CAR, LDR, NPL, BOPO dan FBIR menghasilkan nilai signifikansi 0,949 > 0,05 yang artinya nilai residual telah terdistribusi secara normal.

Tabel 5. Hasil Uji Kolmogorov-Smirnov

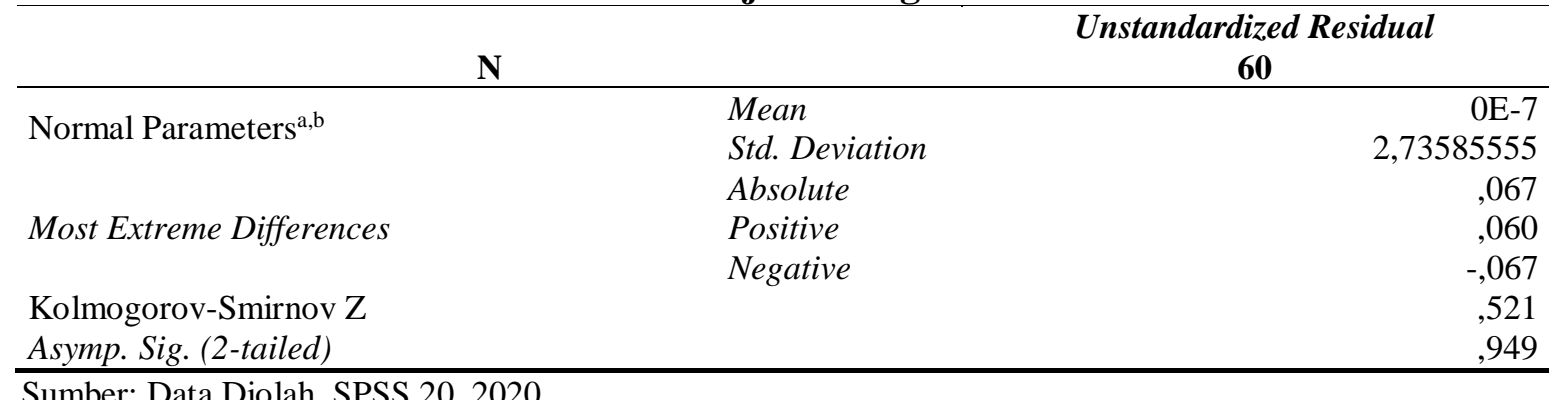

Sumber: Data Diolah, SPSS 20, 2020

Berdasarkan pada hasil uji asumsi klasik maka model kedua untuk regresi berganda tercantum pada Gambar 3. Perihal Model Studi ke-2 tidak lagi memperhitungkan variabel 
LAR sehingga hipotesis ke-empat (Hipotesis4) dengan pernyataan bahwa LAR secara parsial berpengaruh positif signifikan terhadap ROE BUKU III tidak diujikan pada regresi linear berganda karena tidak memenuhi konstruk model.

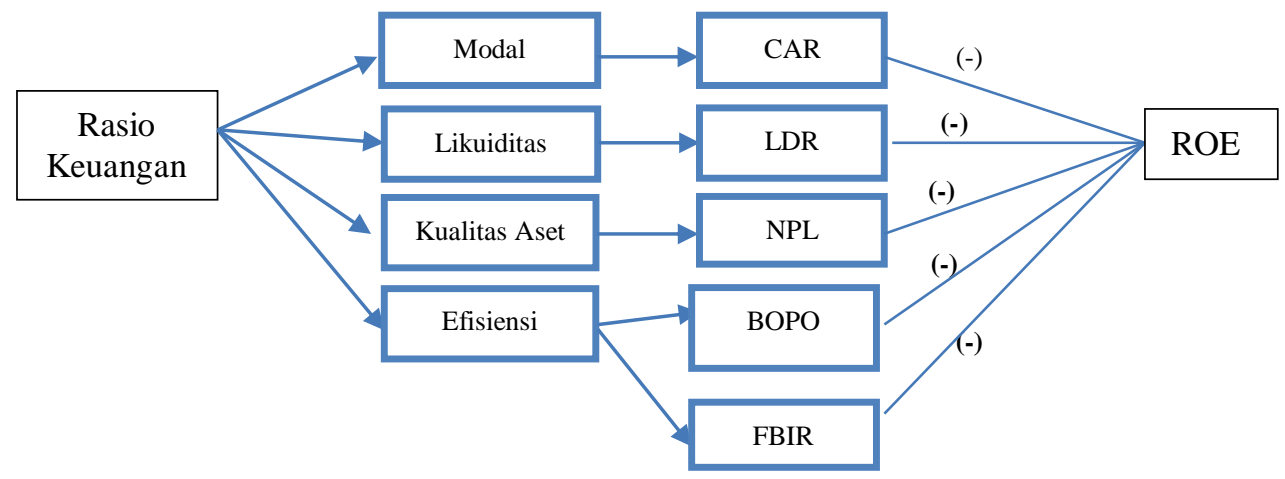

Gambar 3. Model Studi ke-2

Uji simultan berdasarkan pada nilai signifikansi yang merupakan output Anova. Apabila nilai signifikansi $<0,05$ maka $\mathrm{H}_{0}$ ditolak sedangkan $\mathrm{H}_{1}$ diterima (Ghozali, 2016:96) artinya secara simultan sejumlah variabel bebas berpengaruh signifikan terhadap ROE. Jika nilai signifikansi $>0,05$ maka $\mathrm{H}_{0}$ diterima dan $\mathrm{H}_{1}$ ditolak, dengan demikian secara simultan beberapa variabel bebas berpengaruh tidak signifikan terhadap ROE. Pengujian hipotesis secara parsial juga menggunakan nilai signifikansi yang dibandingkan dengan probabilitas 0,05. Jika nilai signifikansi < probabilitas 0,05 maka $\mathrm{H}_{0}$ ditolak, $\mathrm{H}_{1}$ diterima (Ghozali, 2016:97). Artinya variabel bebas berpengaruh signifikan terhadap variabel terikat secara individual. Apabila nilai signifikansi > probabilitas 0,05 maka $\mathrm{H}_{0}$ diterima, $\mathrm{H}_{1}$ ditolak. Berdasarkan ketentuan tersebut maka variabel bebas secara individu berpengaruh tidak signifikan terhadap variabel terikat.

Secara deskriptif rata-rata CAR dari 3 bank sampel pada periode 2015-2019 adalah $16,64 \%$ dan kecenderungannya adalah meningkat sebesar 0,16\%. Namun, rata-rata kecenderungan nilai CAR pada PT Bank Bukopin Tbk pada periode tersebut adalah 0,11\%. PT Bank Mayapada Tbk sebesar 0,20\% dan PT Bank Mega Tbk senilai 0,38\%. Rasio kecukupan modal yang terendah dimiliki oleh PT Bank Bukopin Tbk. Artinya kemampuan PT Bank Bukopin Tbk untuk menanggung risiko dari sejumlah aset produktif yang beresiko cukup rendah sehingga kinerja banknya juga dapat dikatakan mengalami penurunan.

Pada rasio likuiditas yang diukur dengan LDR, rata-rata nilainya terhadap ketiga bank sampel masing-masing adalah 79,10\%. Rata-rata kecenderungan LDR meningkat sebesar 0,36\%. Rata-rata LDR tertinggi dari ketiga bank sampel dimiliki oleh PT Bank Mayapada, 
Tbk sebesar 87,89\%. PT Bank Bukopin sebesar 84,16\% dan yang terendah adalah PT Bank Mega, Tbk senilai 65,25\%. Artinya PT Bank Mayapada Tbk, memiliki kemampuan yang tertinggi untuk memenuhi kewajiban jangka pendek dari sejumlah pinjaman yang disalurkan kepada pihak ketiga dibandingkan kedua bank sampel.

Pengukuran pada rasio kualitas kredit dengan rata-rata kecenderungan nilai NPL bank sampel meningkat sebesar 0,11\%. PT Bank Mega Tbk memiliki nilai rata-rata NPL terkecil 2,63\% sedangkan PT Bank Mayapada Tbk sebesar 3,86\%. NPL tertinggi dimiliki oleh PT Bank Bukopin sebesar 6,57\%. Artinya PT Bank Bukopin Tbk memiliki kualitas kredit yang paling rendah dibandingkan dengan dua bank sampel lainnya, dengan demikian PT Bank Bukopin memiliki risiko kredit yang paling tinggi. Sebaliknya, kualitas kredit yang bagus dimiliki oleh PT Bank Mega Tbk.

Rasio efisiensi bank yang diukur dengan BOPO dan FBIR. Kecenderungan rata-rata BOPO dari ketiga bank sampel adalah meningkat sebesar 0,08\%. Nilai rata-rata BOPO tertinggi dari ketiga bank sampel adalah PT Bank Bukopin Tbk sebesar 90,56\%. Tingkat efisiensi PT Bank Bukopin Tbk dapat diartikan yang paling rendah berkaitan dengan pengelolaan kegiatan operasional bank dibandingkan kedua bank sampel lainnya. Rata-rata BOPO PT Bank Mayapada Tbk, senilai 85,87\% sedangkan yang terendah dimiliki oleh PT Bank Mega Tbk sebesar 80,64\%. PT Bank Mega Tbk merupakan bank yang paling efisien mengelola kegiatan operasionalnya dibandingkan kedua bank sampel. Rata-rata FBIR dari ketiga bank sampel kecenderungannya adalah menurun sebesar 0,20\%. PT Bank Mega Tbk memiliki rata-rata FBIR tertinggi sebesar 25,61\%. Berdasarkan angka tersebut maka dapat diartikan PT Bank Mega Tbk lebih efisien mengelola kegiatan operasionalnya dibandingkan kedua bank sampel. PT Bank BukopinTbk memiliki nilai FBIR 17,19\% dan yang terendah adalah PT Bank Mayapada sebesar 5,14\%.

Secara keseluruhan rata-rata ROE bank sampel adalah 12,95\% dengan rata-rata kecenderungannya menurun senilai $0,51 \%$. Nilai ROE terendah dimiliki oleh PT Bank Bukopin sebesar 9,59\% dan PT Bank Mega Tbk sebesar 13,38\%. PT Bank Mayapada Tbk sebesar 15,88\% sebagai bank sampel dengan perolehan ROE yang tertinggi. Artinya kemampuan menghasilkan laba bersih PT Bank Mayapada Tbk lebih maksimal dibandingkan kedua bank sampel, sedangkan kemampuan perolehan laba bersih terendah adalah PT Bank Bukopin Tbk. Rincian deskripsi rasio dari ketiga bank sampel tercantum pada Tabel 6, perihal Deskripsi Rasio Bank-Bank Sampel. 
Tabel 6. Deskripsi Rasio Bank-Bank Sampel

\begin{tabular}{|c|c|c|c|c|c|c|c|c|c|}
\hline No & Rasio & $\begin{array}{c}\text { Rata- } \\
\text { rata } \\
\text { Bank } \\
\text { Sampel }\end{array}$ & $\begin{array}{c}\text { Rata- } \\
\text { rata } \\
\text { Tren } \\
\text { Bank } \\
\text { Sampel }\end{array}$ & $\begin{array}{c}\text { Rata- } \\
\text { rata } \\
\text { PT Bank } \\
\text { Bukopin } \\
\text { Tbk }\end{array}$ & $\begin{array}{c}\text { Rata- } \\
\text { rata Tren } \\
\text { PT Bank } \\
\text { Bukopin } \\
\text { Tbk }\end{array}$ & $\begin{array}{c}\text { Rata- } \\
\text { rata PT } \\
\text { Bank } \\
\text { Mayapa } \\
\text { da Tbk }\end{array}$ & $\begin{array}{c}\text { Rata-rata } \\
\text { Tren PT } \\
\text { Bank } \\
\text { Mayapad } \\
\text { a Tbk }\end{array}$ & $\begin{array}{c}\text { Rata- } \\
\text { rata PT } \\
\text { Bank } \\
\text { Mega } \\
\text { Tbk }\end{array}$ & $\begin{array}{c}\text { Rata- } \\
\text { rata } \\
\text { Tren } \\
\text { PT } \\
\text { Bank } \\
\text { Mega } \\
\text { Tbk }\end{array}$ \\
\hline 1. & CAR & $16,64 \%$ & $0,16 \%$ & $13,94 \%$ & $-0,11 \%$ & $13,40 \%$ & $0,20 \%$ & $22,58 \%$ & $0,38 \%$ \\
\hline 2. & LDR & $79,10 \%$ & $0,36 \%$ & $84,16 \%$ & $0,24 \%$ & $87,89 \%$ & $0,53 \%$ & $65,25 \%$ & $0,33 \%$ \\
\hline 3. & NPL & $4,35 \%$ & $0,11 \%$ & $6,57 \%$ & $0,29 \%$ & $3,86 \%$ & $0,04 \%$ & $2,63 \%$ & $0,00 \%$ \\
\hline 4. & BOPO & $85,69 \%$ & $0,08 \%$ & $90,56 \%$ & $0,60 \%$ & $85,87 \%$ & $0,16 \%$ & $80,64 \%$ & $-0,51 \%$ \\
\hline 5. & FBIR & $15,98 \%$ & $-0,20 \%$ & $17,19 \%$ & $-0,04 \%$ & $5,14 \%$ & $0,10 \%$ & $25,61 \%$ & $-0,65 \%$ \\
\hline 6. & ROE & $12,95 \%$ & $-0,51 \%$ & $9,59 \%$ & $-0,48 \%$ & $15,88 \%$ & $-0,59 \%$ & $13,38 \%$ & $-0,48 \%$ \\
\hline
\end{tabular}

Sumber: Data Diolah, SPSS 20, 2020

Hasil pengukuran statistik dengan regresi berganda diperoleh persamaan sebagai berikut:

$$
\text { Y=83,550-1,086CAR-0,192LDR-1,336NPL-0,366BOPO-0,010FBIR+ei }
$$

Hasil perhitungan tersebut secara rinci tercantum pada Tabel 4, perihal Hasil Regresi Linier Berganda dapat dilihat pada hasil pengolahan data dibawah ini:

\section{Tabel 7. Hasil Regresi Linier Berganda}

\begin{tabular}{|c|c|c|}
\hline \multirow[t]{2}{*}{ Variabel } & \multicolumn{2}{|c|}{ Koefisien } \\
\hline & B & Std Error \\
\hline Konstanta $(\alpha)$ & 83,550 & 10,464 \\
\hline $\mathbf{X}_{1}=\mathbf{C A R}$ & $-1,086$ & 0,144 \\
\hline $\mathbf{X}_{2}=\mathbf{L D R}$ & $-0,192$ & 0,064 \\
\hline$X_{3}=\mathbf{N P L}$ & $-1,336$ & 0,235 \\
\hline $\mathrm{X}_{4}=\mathrm{BOPO}$ & $-0,366$ & 0,085 \\
\hline $\mathrm{X}_{5}=\mathrm{FBIR}$ & $-0,010$ & 0,055 \\
\hline $\mathrm{R} \quad=\mathbf{0 , 8 8 8}$ & $\mathrm{Sig} \quad=0,000$ & \\
\hline Rsquare $=\mathbf{0 , 7 8 8}$ & Fhitung $=40,137$ & \\
\hline Adjusted $R$ Square $=\mathbf{0 , 7 6 8}$ & & \\
\hline
\end{tabular}

Sumber data diolah: SPSS 20, 20202

\section{Hipotesis Pertama}

Hipotesis pertama menyatakan bahwa rasio modal berupa CAR, rasio likuiditas (LDR), kualitas aset yang diukur dengan NPL serta rasio efisiensi dengan BOPO dan FBIR secara simultan berpengaruh signifikan terhadap ROE BUKU III. Hasil pengujian dengan nilai signifikan $0,00<0,05$ terbukti secara simultan keenam variabel bebas tersebut berpengaruh secara signifikan sehingga $\mathrm{H}_{1}$ dapat diterima. Hasil pengujian ini sejalan dengan hasil penelitian sebelumnya yang dilakuan oleh Aprilia \& Handayani (2018), Pinasti \& Mustikawati (2018), serta Saputri \& Oetomo (2016). 


\section{Hipotesis Kedua}

Hipotesis kedua berdasarkan teori menyatakan bahwa rasio kecukupan modal secara parsial berpengaruh positif signifikan terhadap ROE BUKU III. Hasil pengujian secara parsial rasio kecukupan modal memiliki nilai signifikansi $0,000<0,05$. Artinya rasio tersebut berpengaruh signifikan, namun arah koefisien negatif terhadap ROE, dengan demikian $\mathrm{H}_{2}$ ditolak.

Secara konsep rasio kecukupan modal memiliki pengaruh positif terhadap ROE, sehingga hasil dari studi ini tidak sejalan dengan teori dan hasil penelitian dari Saputri \& Oetomo (2016). Namun, sejalan dengan hasil penelitian oleh Aprilia \& Handayani (2018), Eka Agustyn Nurhayati et al. (2019), Nimah \& Magumi (2019) serta Vellanita et al. (2019).

Hasil studi ini memberikan gambaran bahwa peningkatan rasio kecukupan modal tidak selalu diikuti dengan peningkatan ROE. Hal tersebut terjadi pada sejumlah bank sampel karena pengelolaan terhadap ekuitas-modal belum dilakukan secara efektif. Artinya nilai pengeluaran terhadap Aset Tertimbang Menurut Risiko (ATMR) lebih besar dibandingkan dengan sejumlah modal yang dipergunakan untuk mendanai ATMR tersebut, dengan demikian perolehan laba menurun dan berpengaruh pada penurunan nilai ROE.

\section{Hipotesis Ketiga}

Hipotesis ketiga pada studi ini adalah LDR secara parsial berpengaruh negatif signifikan terhadap ROE BUKU III. Hasil pengujian hipotesis mengungkapkan secara parsial LDR memiliki nilai signifikansi $0,004<0,05$ sehingga LDR memiliki pengaruh yang signifikan terhadap ROE dengan arah koefisien negatif, sehingga $\mathrm{H}_{3}$ ditolak.

Hasil studi ini tidak sejalan dengan teori dan penelitian yang dilakukan oleh Eka Agustyn Nurhayati et al. (2019). Berdasarkan data deskriptif rata-rata nilai LDR ketiga bank sampel kecenderungannya meningkat sebesar 0,36\% namun jumlah kredit yang diberikan lebih besar dibandingkan penghimpunan dana dari pihak ketiga. Semakin besar kredit yang diberikan memberikan potensi yang besar terhadap jumlah kredit bermasalah, sehingga berpengaruh terhadap penurunan laba dan nilai ROE. Artinya ketiga bank sampel memiliki kualitas kredit yang kurang bagus. Hasil ini sejalan dengan penelitian yang dilakukan oleh Nuryanto, Salam, Sari, \& Suleman (2020), Jumono et al. (2019), Vellanita et al. (2019) dan Reza (2018)

\section{Hipotesis Keempat}

Pada studi ini pernyataan dari hipotesis keempat tidak digunakan karena tidak memenuhi salah satu unsur asumsi klasik pada uji multikolonieritas. 


\section{Hipotesis Kelima}

Pernyataan hipotesis kelima pada studi ini adalah NPL secara parsial berpengaruh negatif signifikan terhadap ROE BUKU III. Hasil pengujian secara parsial, NPL dengan arah koefisien negatif memiliki nilai signifikansi $0,000<0,05$ dengan demikian NPL berpengaruh signifikan terhadap ROE dan $\mathrm{H}_{5}$ diterima. Hasil ini sejalan dengan teori dan didukung juga dengan hasil penelitian sebelumnya Prasanto (2020), Reza (2018), Saputri \& Oetomo (2016).

Berdasarkan pada analisis deskriptif terhadap ketiga bank sampel, nilai NPL rata-rata kecenderungannya meningkat sebesar $0,11 \%$. Artinya pada ketiga bank sampel tersebut telah terjadi peningkatan pada total kredit bermasalah yang lebih besar dibandingkan dengan jumlah kredit yang diberikan, sehingga Cadangan Kerugian Penurunan Nilai (CKPN) mengalami peningkatan yang lebih besar dibandingkan dengan pendapatan. Peningkatan NPL menyebabkan laba mengalami penurunan dan ROE juga menurun (Reza, 2018), dengan demikian NPL juga memiliki dampak yang besar terhadap perolehan nilai profitabilitas suatu bank (Prasanto, 2020).

\section{Hipotesis Keenam}

Pernyataan hipotesis keenam pada penilitian ini adalah BOPO secara parsial berpengaruh negatif signifikan terhadap ROE BUKU III. Berdasarkan hasil pengujian, nilai signifikansi BOPO 0,000 < 0,05 dengan demikian BOPO berpengaruh signifikan terhadap ROE dengan arah koefisien negatif, dan $\mathrm{H}_{6}$ diterima. Berdasarkan data deskriptif rata-rata kecenderungan nilai BOPO dari ketiga bank sampel adalah meningkat sebesar 0,08\%. Peningkatan BOPO menggambarkan terjadi peningkatan beban operasional yang lebih besar dibandingkan pendapatan operasional, maka terjadi penurunan efisiensi yang menyebabkan terjadinya penurunan perolehan laba dan berdampak juga pada penurunan ROE. Hasil ini sejalan dengan teori dan didukung juga dengan beberapa penelitian sebelumnya yang dilakukan oleh Pinasti \& Mustikawati (2018), Aprilia \& Handayani (2018), Christaria \& Kurnia (2016) Nimah \& Maguni (2019), Reza (2018) dan Rusiyati (2018).

\section{Hipotesis Ketujuh}

Hipotesis ketujuh adalah FBIR secara parsial berpengaruh positif signifikan terhadap ROE BUKU III. Berdasarkan hasil pengujian FBIR memiliki nilai signifikansi 0,852>0,05 sehingga FBIR memiliki pengaruh yang tidak signifikan terhadap ROE dengan arah koefisien negatif. Berdasarkan pada hasil tersebut maka $\mathrm{H}_{7}$ ditolak. Hasil ini tidak sesuai dengan teori dan tidak sejalan dengan penelitian yang dilakukan oleh Jumono, Sugiyanto, \& Mala (2019) serta Sufian \& Chong (2008). Hasil studi ini sejalan dengan penelitian yang dilakukan oleh Reza (2018). Kecenderungan rata-rata nilai FBIR pada ketiga bank sampel secara desktiptif 
selama periode penelitian sebesar minus $0,20 \%$. Berdasarkan data deskriptif dan uji parsial tersebut dapat diartikan bahwa selama periode studi, ketiga bank sampel mengalami penurunan pada pendapatan operasional selain bunga yang kecenderungannya menurun sebesar 0,20\%. Namun, pada studi ini FBIR tidak memiliki pengaruh yang signifikan terhadap perolehan laba bersih dan perhitungan rasio profitabilitas ROE.

Secara rinci hasil uji parsial (uji-t) terhadap tiga bank sampel tercantum pada Tabel 8. Berdasarkan tabel tersebut dapat diketahui bahwa variabel CAR, LDR, NPL dan BOPO merupakan variabel yang berpengaruh terhadap perolehan profitabilitas yang diukur dengan ROE terhadap ketiga bank sampel. Variabel independen yang paling dominan mempengaruhi tingkat profitabilitas ketiga bank sampel sebagai bagian dari BUKU III adalah rasio kecukupan modal (CAR) dengan kontribusi sebesar 51,4\% terhadap ROE.

Tabel 8. Hasil Uji Parsial (Uji-t

\begin{tabular}{|c|c|c|c|c|c|c|c|}
\hline \multirow[t]{2}{*}{ Variabel } & \multicolumn{2}{|c|}{$\begin{array}{c}\text { Unstandardized } \\
\text { Coefficients }\end{array}$} & \multirow{2}{*}{$\begin{array}{c}\begin{array}{c}\text { Standardized } \\
\text { Coefficients }\end{array} \\
\text { Beta }\end{array}$} & \multirow[t]{2}{*}{$\mathbf{t}$} & \multirow[t]{2}{*}{ Sig } & \multirow[t]{2}{*}{$\mathbf{r}$} & \multirow[t]{2}{*}{ r2 } \\
\hline & B & $\begin{array}{c}\text { Std } \\
\text { Error }\end{array}$ & & & & & \\
\hline 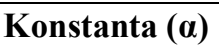 & 83,550 & 10,464 & - & 7,984 & 0,000 & - & - \\
\hline $\mathrm{X}_{1}=\mathrm{CAR}$ & $-1,086$ & 0,144 & $-0,871$ & $-7,562$ & 0,000 & $-0,717$ & 0,5140 \\
\hline $\mathrm{X}_{2}=\mathbf{L D R}$ & $-0,192$ & 0,064 & $-0,364$ & $-2,980$ & 0,004 & $-0,376$ & 0,1414 \\
\hline $\mathbf{X}_{\mathbf{3}}=\mathbf{N P L}$ & -1.336 & 0,235 & $-0,592$ & $-5,688$ & 0,000 & $-0,612$ & 0,3745 \\
\hline $\mathrm{X}_{4}=\mathrm{BOPO}$ & $-0,366$ & 0,085 & $-0,455$ & $-4,310$ & 0,000 & $-0,506$ & 0,2560 \\
\hline $\mathrm{X}_{5}=\mathrm{FBIR}$ & $-0,010$ & 0,055 & $-0,144$ & $-0,187$ & 0,852 & $-0,025$ & 0,0006 \\
\hline
\end{tabular}

Sumber : Data Diolah, SPSS 20, 2020

\section{KESIMPULAN DAN SARAN}

Berdasarkan hasil pengolahan data dan analisis beberapa kesimpulan dari studi ini adalah sebagai berikut: Pada studi ini rasio likuiditas diukur dengan LDR, tidak menggunakan LAR karena variabel tersebut tidak memenuhi model asumsi klasik. Kemudian Rasio modal yang diukur dengan rasio kecukupan modal, likuiditas dengan variabel LDR, kualitas aset dengan NPL dan efisiensi dengan BOPO dan FBIR secara simultan berpengaruh signifikan terhadap profitabilitas yang diukur dengan ROE pada kelompok BUKU III. Berdasarkan hasil uji parsial, rasio kecukupan modal, LDR, NPL dan BOPO merupakan variabel beban yang berpengaruh negatif signifikan terhadap ROE, sedangkan FBIR tidak memiliki pengaruh terhadap ROE. Sementara Rasio kecukupan modal (CAR) merupakan variabel bebas yang paling dominan berpengaruh terhadap ROE sebesar 51,4\% . Hasil studi ini berimplikasi terhadap manajemen bank yang berkaitan dengan pemenuhan modal menjadi perhatian khusus bank terutama pemenuhan kecukupan modal sebesar 8\% (POJK No 11/POJK.03, 2016). Pemenuhan terhadap kecukupan modal bank menggambarkan bank mampu menyerap 
sejumlah kerugian operasional secara efisien. Hal terpenting yang menjadi perhatian pihak manajemen bank adalah kualitas aset yang berupa NPL serta tingkat likuiditas yang berkaitan dengan LDR dan rasio efisiensi BOPO sebagai bagian dari rasio keuangan, sedangkan FBIR terkait dengan studi ini tidak menjadi rasio keuangan yang berpengaruh terhadap ROE.

Berkaitan dengan tiga bank sampel dari studi ini, secara khusus terhadap PT Bank Bukopin Tbk, perlu memperhatikan kecukupan modalnya karena secara deskriptif rata-rata kecenderungannya telah menurun sebesar $0,11 \%$ yang berakibat pada penurunan laba dan menurunnya rata-rata kecenderungan ROE senilai $0,48 \%$. Penurunan rasio profitabilitas ROE PT Bank Bukopin Tbk juga disebabkan oleh peningkatan NPL yang rata-rata kecenderungannya meningkat sebesar 0,29\%. Peningkatan tersebut paling tinggi jika dibandingkan dengan kedua bank sampel. Peningkatan NPL dari PT Bank Bukopin Tbk mengindikasikan telah terjadi peningkatan jumlah kredit yang bermasalah, artinya pembayaran sejumlah kredit yang disalurkan banyak mengalami penundaan sehingga kategorinya tidak lancar. Kondisi tersebut mengakibatkan perolehan laba menurun dan ROE juga menurun.

Berdasarkan beberapa kesimpulan tersebut maka saran berkaitan dengan bank sampel terutama PT Bank Bukopin Tbk, adalah melakukan peningkatan profitabilitas pada perolehan laba secara efektif dan efisien dengan memperhatikan rasio kecukupan modal, membenahi sejumlah kredit yang bermasalah melalui resktrukturisasi kredit yang pada akhirnya akan menurunkan beban operasional sehingga terjadi peningkatan pada rasio efisiensi bank Berkaitan dengan studi selanjutnya ada baiknya memperhitungkan rasio Interest Rate of Return (IRR) atau Posisi Devisa Neto (PDN), karena studi ini belum memperhitungkan sensitivitas pasar sebagai bagian dari faktor eksternal.

\section{REFERENSI}

Aprilia, J., \& Handayani, S. R. (2018). Pengaruh Capital Adequacy Ratio, Biaya Operasional Per Pendapatan Operasional, Non Performing Loan, dan Loan to Deposit Ratio terhadap Return On Asset Dan Return On Equity. Jurnal Administrasi Bisnis (Jab), 61(3), 172182. Retrieved From http://Administrasibisnis studentjournal.Ub.Ac.Id/Index.Php/Jab/Article/Viewfile/2611/3005

Bourke, P. (1989). Concentration and Other Determinants of Bank Profitability in Europe, North America and Australia. Journal of Banking and Finance. Https://Doi.Org/10.1016/0378-4266(89)90020-4

Christaria, F., \& Kurnia, R. (2016). The Impact of Financial Ratios, Operational Efficiency and Non Performing Loan Towards Commercial Bank Profitability. Global Academy Of Training \& Research Journal.

Eka Agustyn Nurhayati, Sudiyatno, B., \& Elen Puspitasari. (2019). Penentu Profitabilitas pada Bank Konvensional yang Terdaftar di BEI Tahun 2015-2017. Dinamika Akuntansi, 
Keuangan dan Perbankan, 8(2), 109-116.

Ghozali, I. (2016). Aplikasi Analisis Multivariate dengan Program Ibm SPSS 23.

Jumono, S., Sugiyanto, \& Mala, C. M. F. (2019). Determinants of Profitability in Banking Industry: a Case Study of Indonesia. International Journal of English Language and Literature Studies. Https://Doi.Org/10.18488/Journal.Aefr.2019.91.91.108

Kiesi, D. E., Weygandt, J. J., \& Warfield, T. D. (2018). Intermediate Accounting: Ifrs Edition. Wiley. Https://Doi.Org/10.1017/Cbo9781107415324.004

Menicucci, E., \& Paolucci, G. (2016). The Determinants of Bank Profitability: Empirical Evidence from European Banking Sector. Journal of Financial Reporting and Accounting. Https://Doi.Org/10.1108/Jfra-05-2015-0060

Molyneux, P., \& Thornton, J. (1992). Determinants of European Bank Profitability: a Note. Journal of Banking and Finance. Https://Doi.Org/10.1016/0378-4266(92)90065-8

Nimah, F., \& Maguni, W. (2019). The Effect of Financial Ratio (CAR, FDR, NPF and BOPO) on The Profitability Level in PT Bank Muamalat Indonesia Tbk. Global Journal of Management and Business Research: C Finance, 19(7), 22-34.

Nuryanto, U. W., Salam, A. F., Sari, R. P., \& Suleman, D. (2020). Pengaruh Rasio Kecukupan Modal, Likuiditas, Risiko Kredit dan Efisiensi Biaya terhadap Profitabilitas pada Bank Go Public. Moneter - Jurnal Akuntansi dan Keuangan. Https://Doi.Org/10.31294/Moneter.V7i1.6777

Otoritas Jasa Keuangan. (2016a). Pojk No. 6/Pojk.03/2016. Kegiatan Usaha dan Jaringan Kantor Berdasarkan Modal Inti Bank. Retrieved From Www.Ojk.Go.Id

Otoritas Jasa Keuangan. (2016b). Surat Edaran Otoritas Jasa Keuangan Nomor 43/Seojk/2016.

Otoritas Jasa Keuangan. (2018). Pojk. Peraturan Otoritas Jasa Keuangan No 33/Pojk.03/2018, 1-68.

Pojk No 11/Pojk.03. (2016). Otoritas Jasa Keuangan Republik Indonesia. Peraturan Otoritas Jasa Keuangan, (Kewajiban Penyediaan Modal Minimum Bank Umum), 1-38.

Prasanto, O. D. W. B. S. N. M. K. (2020). Determinants of Bank Profitability: A New Evidence from State-Owned Banks in Indonesia. Trikonomika, 19(1), 29-35. Https://Doi.Org/10.23969/Trikonomika.V19i1.1443

Reza, A. Y. (2018). Pengaruh Rasio Likuiditas, Rasio Kualitas Aktiva, Rasio Sensitivitas Pasar dan Rasio Efisiensi terhadap Return on Equity pada Bank Umum Swasta Nasional Devisa. Eprint Stie Perbanas Surabaya. Retrieved From Http://Eprints.Perbanas.Ac.Id/3991/

Rivai, V., Basir, S., Sudarto, S., \& Arifiandy Permata Veithzal. (2013). Commercial Bank Management Manajemen Perbankan dari Teori ke Praktik. Jakarta: Rajagrafindo Persada. Https://Doi.Org/10.1371/Journal.Pone.0013666

Rusiyati, S. (2018). Pengaruh Rasio Keuangan terhadap Profitabilitas pada Bank Persero di Bursa Efek Indonesia. Jurnal Moneter Akuntansi Dan Keuangan Vol.5 No.2.

Saputri, S. F. H., \& Oetomo, H. W. (2016). Pengaruh CAR, BOPO, NPL dan FDR terhadap ROE pada Bank Devisa. Jurnal Ilmu \& Riset Manajemen.

Subramanyam, K. R. (2014). Financial Statement Analysis : Eleventh Edition. Mcgraw-Hill Education. Https://Doi.Org/10.1017/Cbo9781107415324.004

Sufian, C. And. (2008). Determinats of Bank Profitability in a Developing Economy: Empirical Evidence from The Philippines. Asian Academcy of Managemnet Journal of Accounting and Finance.

Susilowati, E. M., \& Tiningrum, E. (2019). Tata Kelola Perbankan ditinjau dari Kinerja Keuangan dilihat dari Profitabilitas Perbankan. Ekonomi Dan Perbankan.

Vellanita, A., Arimbawa, I. G., \& Damayanti, E. (2019). Relationship Between Non Performing Loans (NPL), Capital Adequacy Ratio (CAR), Loan To Deposit Ratio 
(LDR) Towards Return On Equity (ROE) at PT . Bank Central Asia 2014 - 2018 (Pp. 211-216). 